\title{
Energy End-Use Efficiency
}

\author{
Amory B. Lovins, CEO, Rocky Mountain Institute \\ 1739 Snowmass Creek Road, Snowmass CO 81654-9115, USA \\ www.rmi.org, ablovins@ rmi.org \\ 19 September 2005
}

Commissioned by InterAcademy Council, Amsterdam, www.interacademycouncil.net, as part of its 2005-06 study “Transitions to Sustainable Energy Systems." Copyright (C 2005 IAC. All rights reserved. Nonprofit reproduction and posting rights (with attribution \& acknowledgement) are licensed to Rocky Mountain Institute. See Lovins (2004) for definitions of key terms.

\section{Importance}

Increasing energy end-use efficiency-technologically providing more desired service per unit of delivered energy consumed-is generally the largest, least expensive, most benign, most quickly deployable, least visible, least understood, and most neglected way to provide energy services. The $46 \%$ drop in U.S. energy intensity (primary energy consumption per dollar of real GDP) during 1975-2005 represented by 2005 an effective energy "source" $2.1 \times$ as big as U.S. oil consumption, $3.4 \times$ net oil imports, $6 \times$ domestic oil output or net oil imports from OPEC countries, and $13 \times$ net imports from Persian Gulf countries. U.S. energy intensity has lately fallen by $\sim 2.5 \%$ per year, apparently due much more to improved efficiency than to changes in behavior or in the mix of goods and services provided, and outpacing the growth of any fossil or nuclear source. Yet energy efficiency has gained little attention or respect. Indeed, since official statistics focus $\sim 99 \%$ on physical energy supply, only the fifth of the 1996-2005 increase in U.S. energy services that came from supply was visible to investors and policymakers; the four-fifths saved was not. The last time this incomplete picture led to strongly supply-boosting national policies, in the early 1980s, it caused a trainwreck within a few years-glutted markets, crashed prices, bankrupt suppliers-because the market had meanwhile invisibly produced a gusher of efficiency. Savings were deployed faster than the big, slow, lumpy supply expansions, whose forecast revenues disappeared. Today we have $t w o$ fast competitors: efficiency and micropower.

Physical scientists find that despite energy efficiency's leading role in providing new energy services today, it has barely begun to tap its profitable potential. In contrast, many engineers tend to be limited by adherence to past practice, and most economists by their assumption that any profitable savings must already have occurred. The potential of energy efficiency is also increasing faster through innovative designs, technologies, policies, and marketing methods than it is being used up through gradual implementation. The uncaptured "efficiency resource" is becoming bigger and cheaper even faster than oil reserves have lately done through stunning advances in exploration and production. The expansion of the "efficiency resource" is also accelerating, as designers realize that whole-system design integration (Part 4) can often make very large (one- or two-order-of-magnitude) energy savings cost less than small or no savings, and as energy-saving technologies evolve discontinuously rather than incrementally. Moreover, simi- 
larly rapid evolution and enormous potential apply also to marketing and delivering energysaving technologies and designs; R\&D can accelerate both.

\section{A. Terminology}

"Efficiency" means different things to the two professions most engaged in achieving it. To engineers, "efficiency" means a physical output/input ratio. To economists, "efficiency" means a monetary output/input ratio (though for practical purposes many use a monetary output/physical input ratio) — and also, confusingly, "efficiency" may refer to the economic optimality of a market transaction or process. This paper uses only physical output/input ratios, but the common use of monetary ratios confuses policymakers accustomed to economic jargon.

Wringing more work from energy via smarter technologies is often, and sometimes deliberately, confused with a pejorative usage of the ambiguous term "energy conservation." Energy efficiency means doing more (and often better) with less-the opposite of simply doing less or worse or without. This confusion unfortunately makes the honorable and traditional term "energy conservation" no longer useful in certain societies, notably the United States, and underlies much of their decades-long neglect or suppression of energy efficiency.

However, deliberately reducing the amount or quality of energy services remains a legitimate, though completely separate, option for those who prefer it or are forced by emergency to accept it. The 2000-01 California electricity crisis ended abruptly when customers, exhorted to curtail their use of electricity, cut their peak load per dollar of weather-adjusted real GDP by $14 \%$ in the first half of 2001. Most of that dramatic reduction, undoing the previous 5-10 years' demand growth, was temporary and behavioral, but later became permanent and technological. Even absent crises, some people do not consider an ever-growing volume of energy services to be a worthy end in itself, but seek to live more simply-with elegant frugality rather than involuntary penury - and to meet nonmaterial needs by nonmaterial means. (Trying to do otherwise is ultimately futile.) Such choices can save even more energy than technical improvement alone, though they are often considered beyond the scope of energy efficiency.

Several other terminological distinctions are also important:

- At least five different kinds of energy efficiency can be measured in at least five different stages of energy conversion chains (Part 1B), but this paper is only on end-use efficiency.

- Technical improvements in energy efficiency can be applied only to new buildings and equipment, or installable in existing ones ("retrofitted"), or addable during minor or routine maintenance ("slipstreamed"), or conveniently added when making major renovations or expansions for other reasons ("piggybacked").

- Efficiency saves energy whenever an energy service is being delivered, whereas load management (sometimes called demand response to emphasize reliance on customer choice) only changes the time when that energy is used-either by shifting the timing of the service delivery or by, for example, storing heat or coolth so energy consumption and service delivery can occur at different times. In the context chiefly of electricity, demandside management, a term coined by the [U.S.] Electric Power Research Institute, comprises both these options, plus others that may even increase the use of electricity. Most efficiency options yield comparable or greater savings in peak loads; both kinds of savings are valuable, and both kinds of value should be counted. They also have important but seldom-recognized linkages: for example, because most U.S. peak electric loads are met by extremely inefficient simple-cycle gas-fired combustion turbines, saving $1 \%$ of 
U.S. electricity, including peak hours, reduces total natural-gas consumption by $2 \%$ and cuts its price by 3-4\% (Lovins, Datta, et al. 2004).

- Conflating three different things-technological improvements in energy efficiency (such as thermal insulation), behavioral changes (such as resetting thermostats), and the price or policy tools used to induce or reward those changes-causes endless confusion.

- The theoretical potential for efficiency gains (up to the maximum permitted by the laws of physics) exceeds the technical potential, which exceeds the economic potential based on social value, which exceeds the economic potential based on private internal value, which exceeds the actual uptake not blocked by market failures, which exceeds what happens spontaneously if no effort is made to accelerate efficiency gains deliberately; yet these six quantities are often not clearly distinguished.

- Energy statistics are traditionally organized by the economic sector of apparent consumption, not by the physical end-uses provided or services sought. End-uses were first seriously analyzed in 1976, rarely appear in official statistics even three decades later, and can be hard to estimate accurately. But end-use analysis can be valuable because matching energy supplies in quality and scale, as well as in quantity, to end-use needs can save much energy and money. Supplying energy of superfluous quality, not just quantity, for the task is wasteful and expensive. For example, the U.S. now provides about twice as much electricity as the fraction of end-uses that economically justify this special, costly, high-quality form of energy-yet during 1975-2000, 45\% of the total growth in primary energy consumption came from increased conversion and grid losses in the expanding, very costly, and heavily subsidized electricity system. Much of the electric growth, in turn, provided low-temperature heat-a physically and economically wasteful use of electricity, an extremely high-quality and costly carrier.

Many subtleties of defining and measuring energy efficiency merit but seldom get rigorous treatment, such as:

- distribution losses downstream of end-use devices (an efficient furnace feeding leaky ducts or poorly distributing the heated air yields costlier delivered comfort);

- undesired or useless services, such as leaving equipment on all the time (as many factories do) even when it serves no useful purpose;

- misused services, such as space-conditioning rooms that are open to the outdoors;

- conflicting services, such as heating and cooling the same space simultaneously (wasteful even if both services are provided efficiently);

- parasitic loads, as when the inefficiencies of a central cooling system reappear as additional fed-back cooling loads that make the system less efficient than the sum of its parts;

- misplaced efficiency, such as doing with energy-using equipment, however efficiently, a task that doesn't need the equipment-such as cooling with a mechanical chiller when groundwater or ambient conditions can more cheaply do the same thing; and

- incorrect metrics, such as measuring lighting by raw quantity (lux) unadjusted for its visual effectiveness (Equivalent Sphere Illuminance), which may actually decrease if greater illuminance is improperly delivered, causing veiling reflections and uncomfortable glare.

To forestall a few other semantic quibbles:

- Physicists (including the author) know that energy is not "consumed," as economists' term "consumption" implies, nor "lost," as engineers refer to unwanted conversions into less useful forms. Energy is only converted from one form to another; yet the common metaphors are clear, common, and adopted here. Thus an $80 \%$-efficient motor converts 
its electricity input into $80 \%$ torque and $20 \%$ heat, noise, vibration, and stray electromagnetic fields; the total equals $100 \%$ of the electricity input, or roughly $30 \%$ of the fuel input at a classical thermal power station. (Note that this definition of efficiency combines engineering metrics with human preference. The motor's efficiency may change, with no change in the motor, if changing intention alters which of the outputs are desired and which are unwanted: the definition of "waste" is as much social or contextual as physical. An incandescent floodlamp used to keep plates of food warm in a restaurant may be effective for that purpose even though it is an inefficient source of visible light.)

- More productive use of energy is not, strictly speaking, a physical "source" of energy but is only a way to displace physical sources. This distinction is rhetorical, since the displacement or substitution is real and makes supply fully fungible with efficiency.

- Energy/GDP ratios are a very rough, aggregated, and sometimes misleading metric, because they combine changes in technical efficiency, human behavior, and the composition of GDP (a metric that problematically conflates goods and services with bads and nuisances, counts only monetized activities, and is an increasingly perverse measure of well-being). Yet the $46 \%$ drop in U.S. energy intensity and the 52\% drop in oil intensity during 1975-2004 reflect mainly better technical efficiency. Joseph Romm has also shown that an important compositional shift of U.S. GDP - the information economy emerging in the late 1990s-has significantly decreased energy and probably electrical energy intensity, as bytes substituted for (or increased the capacity utilization of) travel, freight transport, lit and conditioned floorspace, paper, and other energy-intensive goods and services.

The aim here is not to get mired in word games, but to offer a clear overview of what kinds of energy efficiency are available, what they can do, and how best to consider and adopt them.

\section{B. Efficiency along energy conversion chains}

The technical efficiency of using energy is the product of efficiencies successively applied along the chain of energy conversions: the conversion efficiency of primary into secondary energy, times the distribution efficiency of delivering that secondary energy from the point of conversion to the point of end-use, times the end-use efficiency of converting the delivered secondary energy into such desired energy services as hot showers and cold beer. Some analysts add another term at the upstream end-the extractive efficiency of converting fuel in the ground, wind or sun in the atmosphere, etc. into the primary energy fed into the initial conversion device-and another term at the downstream end - the hedonic efficiency of converting delivered energy services into human welfare. (Delivering junk mail with high technical efficiency is futile if the recipients didn't want it.)

Counting all five efficiencies permits comparing ultimate means-primary energy tapped - with ultimate ends - happiness or economic welfare created. Focusing only on intermediate means and ends loses sight of what human purposes an energy system is to serve. Most societies pay attention to only three kinds of energy efficiency: extraction (because of its cost, not because the extracted fuels are assigned any intrinsic or depletion value), conversion, and perhaps distribution. End-use and hedonic efficiency are left to customers, are least exploited, and hence hold the biggest potential gains.

They also offer the greatest potential leverage. Since successive efficiencies along the conversion chain all multiply, they are often assumed to be equally important. Yet downstream 
savings - those nearest the customer-are the most important. Fig. 1 shows schematically the successive energy conversions and losses that require about ten units of fuel to be fed into a conventional thermal power station in order to deliver one unit of flow in a pipe. But conversely, every unit of flow (or friction) saved in the pipe will save approximately ten units of fuel, cost, pollution, and "global weirding" at the power station. It will also make the pump's motor (for example) nearly two and a half units smaller, hence cheaper. To save the most primary energy and the most capital cost, therefore, efficiency efforts should start all the way downstream (Part 4B), by asking: How little flow can actually deliver the desired service? How small can the piping friction become? How small, well-matched to the flow regime, and efficient can the pump be made? Its coupling? Its motor? Its controls and electrical supplies?

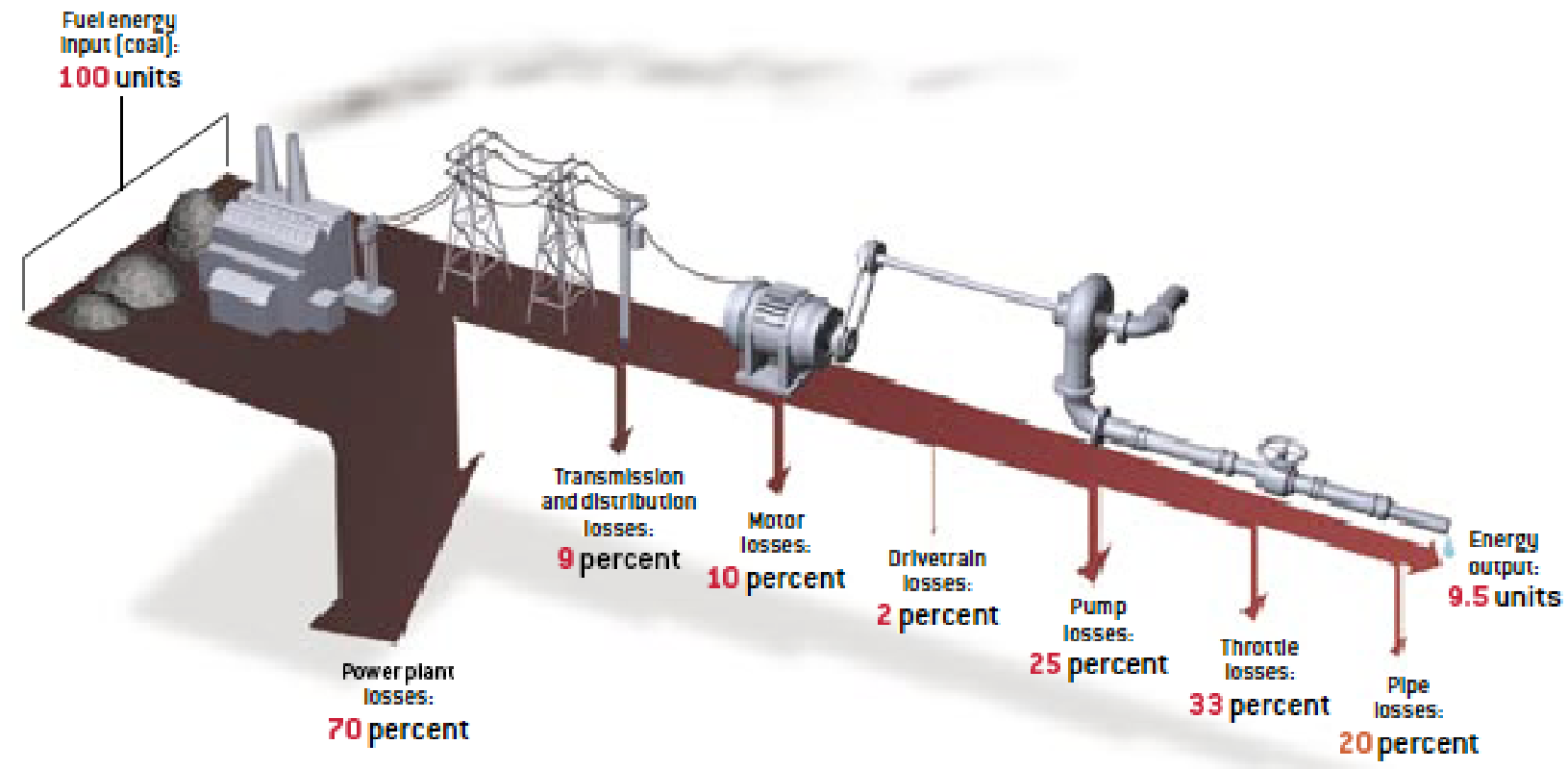

Fig. 1, reproduced by permission from the author's Scientific American paper, 9/05, pp. 74-83.

Analyses of energy use should, but seldom do, start with the desired services or changes in well-being, then work back upstream to primary supplies. This maximizes the extra value of downstream efficiency gains and the capital-cost savings from smaller, simpler, cheaper upstream equipment. Similarly, most energy policy analysts analyze how much energy could be supplied before asking how much is optimally needed and at what quality and scale it could be optimally provided. This backwards direction (upstream to downstream) and supply orientation lie at the root of many if not most energy policy problems.

Even modest improvements in efficiency at each step of the conversion chain can multiply to large collective values. For example, suppose that during 2000-50, world population and economic growth increased economic activity by $6-8 \times$, in line with conventional projections. But meanwhile, the carbon intensity of primary fuel, following a two-century trend, is likely to fall by at least $2-4 \times$ as coal gives way to gas, renewables, and carbon offsets or sequestration. Conversion efficiency is likely to increase by at least $1.5 \times$ with modernized, better-run, combined-cycle, and cogenerating power stations. Distribution efficiency should improve modestly. End-use efficiency could improve by $4-6 \times$ if the intensity reductions sustained by many 
industrial countries when they were paying attention were sustained for 50 years (e.g., the U.S. decreased its primary energy/GDP intensity at an average rate of 3.4\%/y during 1979-86 and 3.0\%/y during 1996-2001). And the least-understood term, hedonic efficiency, might remain constant or might perhaps double as better business models and customer choice systematically improve the quality of services delivered and their match to what customers want. On these plausible assumptions, global carbon emissions from burning fossil fuel could decrease by $1.5-12 \times$ despite the assumed 6-8× grosser World Product. The most important assumption is sustained success with end-use efficiency, but the decarbonization and conversion-efficiency terms also appear able to take up some slack if needed.

\section{Service redefinition}

Some major opportunities to save energy redefine the service being provided. This is often a cultural variable. A Japanese person, asked why the house isn't heated in winter, might reply, "Why should I? Is the house cold?" In Japanese culture, the traditional goal is to keep the person comfortable, not to heat or cool empty space. Thus a modern Japanese room air conditioner may contain a sensor array and swiveling louvers that detect and blow air toward people's locations in the room, rather than wastefully cooling the entire space. Western office workers, too, can save energy (and can often see better, feel less tired, and improve aesthetics) by properly adjusting Venetian blinds, bouncing glare-free daylight up onto the ceiling, and turning off the lights. As Jørgen Nørgård remarks, "Energy-efficient lamps save the most energy when they are turned off"; yet many Westerners automatically turn on every light when entering a room.

This example also illustrates that energy efficiency may be hard to distinguish from energy supply that comes from natural energy flows. All houses are already $~ 98 \%$ solar-heated, because if there were no Sun (which provides $99.8 \%$ of the Earth's heat), the temperature of the Earth's surface would average approximately $-272.6^{\circ} \mathrm{C}$ rather than $+15^{\circ} \mathrm{C}$. Thus, strictly speaking, engineered heating systems provide only the last $1-2 \%$ of the total heating required.

Service redefinition becomes complex in personal transport. Its efficiency is not just about vehicular fuel economy, people per car, or public transport alternatives. Rather, the underlying service should often be defined as access, not mobility. Typically the best way to gain access to a place is to be there already, so one needn't go somewhere else. This is the realm of spatial planning - no novelty in the U.S., where it's officially shunned yet practiced (zoning laws mandate dispersion of location and function, real-estate practices segregate housing by income, and other market distortions maximize unneeded and often unwanted travel). Obviously sprawl would decrease if not mandated and subsidized. Another way to gain access is virtually-moving just the electrons while leaving the heavy nuclei behind-via telecommunications, soon including realistic "virtual presence." Sometimes that's a realistic alternative to physically moving flesh. And if such movement is really necessary, it merits real competition, at honest prices, between all modes: personal or collective, motorized or human-powered, conventional or innovative. Creative policy tools can enhance that choice in ways that enhance property value, saved time, quality of life, and public amenity and security. Efficient cars can be an important part of efficient personal mobility, and (importantly) are vehicles for emotions as well as for bodies, but also reducing the need to drive can save even more energy and yield greater total benefit.

\section{Historic summaries of potential}


People have been saving energy for centuries, even millennia; this is the essence of engineering. Most savings were initially in conversion and end-use: pre-industrial households often used more primary energy than modern ones do, because fuelwood-to-charcoal conversion, inefficient open fires, and crude stoves burned much fuel to deliver sparse cooking and warmth. Lighting, materials processing, and transport end-uses were also very inefficient. Billions of human beings still suffer such primitive conditions today. Developing countries' primary energy/GDP intensities average $\sim 3 \times$ those of industrialized countries. Corrected for purchasing power, China's energy intensity is $\sim 3 \times$ that of the U.S., $\sim 5 \times$ of the E.U., and $\sim 9 \times$ of Japan. Fastgrowing economies like China's have the greatest need and the greatest opportunity to leapfrog to efficiency. But even the most energy-efficient societies still have enormous and expanding room for further efficiency gains. Less than one-fourth of the energy delivered to a typical European cookstove ends up in food; less than one percent of the fuel delivered to a standard car actually moves the driver; U.S. power plants discard waste heat equivalent to $1.2 \times$ Japan's total energy use; and even Japan's economy doesn't approach one-tenth the efficiency that the laws of physics permit. Nor is energy efficiency the end of the story: e.g., not only are Chinese shaft kilns an extremely energy-wasteful way to make cement, but the cement is of such poor and uncertain quality that manyfold more of it must be used to make each $\mathrm{m}^{3}$ of concrete with a certain strength, so the energy leverage of a modern cement plant is these terms' product-and the carbon leverage is then multiplied by switching to any no- or low-carbon fuel.

Detailed and exhaustively documented engineering analyses of the scope for improving energy efficiency, especially in end-use devices, have been published for many industrial and some developing countries. By the early 1980s, those analyses had compellingly shown that most of the energy currently used was being wasted-i.e., that the same or better services could be provided using several-fold less primary energy by fully installing, wherever practical and profitable, the most efficient conversion and end-use technologies then available. Such impressive efficiency gains cost considerably less than the long-run, and often even the short-run, marginal private internal cost of supplying more energy. Most policymakers ignore both these analyses, well-known to specialists, and the less-well-known findings showing even bigger and cheaper savings from whole-system design integration (Part 4). Despite much higher E.U. energy consciousness, policymakers still greatly underestimate efficiency's potential, while in the U.S., national policymakers in the past 20 years have forgotten more than they learned in the previous 20 years, leaving efficiency to be advanced instead by private-sector, local, and state choices.

Many published engineering analyses show a smaller saving potential because of major conservatisms, often deliberate (because the real figures seem too good to be true), or because they assume only partial adoption over a short period rather than examining the ultimate potential for complete practical adoption. For example, the American Council for an Energy-Efficient Economy estimates that just reasonable adoption of the top five conventional U.S. opportunities-industrial improvements, 4.88 L/100 km light-vehicle standards, cogeneration, better building codes, and a 30\%-better central-air-conditioning standard-could save 530 million T/y of oil-equivalent-respectively equivalent to the total 2000 primary energy use of Australia, Mexico, Spain, Austria, and Ireland. But the full long-term efficiency potential is far larger, much of it in many small terms. Saving energy is like eating an Atlantic lobster: there are big, obvious chunks of meat in the tail and the front claws, but there's also a similar total quantity of tasty morsels hidden in crevices and requiring some skill and persistence to extract.

The whole-lobster potential is best, though still not fully, seen in bottom-up technological analyses comparing the quantity of potential energy savings with their marginal cost. That cost is 
typically calculated using the Lawrence Berkeley National Laboratory methodology, which divides the marginal cost of buying, installing, and maintaining the more efficient device by its discounted stream of lifetime energy savings. The levelized cost in dollars of saving, say, $1 \mathrm{~kW}-\mathrm{h}$ then equals $\left.\mathrm{Ci} / S\left[1-(1+i)^{-n}\right)\right]$, where $C$ is installed capital cost $(\$), i$ is annual real discount rate (assumed here to be 0.05), $S$ is energy saved by the device (kW-h/y), and $n$ is operating life (y). Thus a $\$ 10$ device that saved $100 \mathrm{~kW}-\mathrm{h} / \mathrm{y}$ and lasted $20 \mathrm{y}$ would have a levelized "cost of saved energy" (CSE) of $0.8 \phi / \mathrm{kW}-\mathrm{h}$. Against a $5 \phi / \mathrm{kW}$-h electricity price, a 20-y device with a 1-y simple payback would have $\mathrm{CSE}=0.4 \phi / \mathrm{kW}-\mathrm{h}$. It is then conventional for engineering-oriented analysts to represent efficiency "resources" as a supply curve, rather than as shifts along a demand curve (the convention among economists). CSE is methodologically equivalent to the cost of supplied energy (e.g., from a power station and grid): the price of the energy saved is not part of the calculation. Whether the saving is cost-effective depends on comparing the cost of achieving it with the avoided cost of the energy saved. (As Part 2 notes, this conventional engineeringeconomic approach materially understates the benefits of energy efficiency.)

On this basis, the author's analyses in the late 1980s found, from measured cost and performance data for more than 1,000 electricity-saving end-use technologies, that their full practical retrofit could save about three-fourths of U.S. electricity at an average CSE $\sim 0.9 \notin / \mathrm{kWh}(2004$ \$)_roughly consistent with a 1990 Electric Power Research Institute analysis whose differences were mainly methodological rather than substantive. So many key technologies, now in Asian mass production, are now far cheaper yet more effective that today's potential is even larger and cheaper. (The analyses explicitly excluded the small financing and transaction costs. A huge literature accurately predicts and rigorously measures the empirical size, speed, and cost of efficiency improvements delivered by actual utility and government programs.)

Such findings are broadly consistent with equally or more detailed ones by European analysts: for example, that late-1980s technologies could save three-fourths of Danish buildings' electricity or half of all Swedish electricity at $\$ 0.024 / \mathrm{kW}-\mathrm{h}(2004 \$)$, or four-fifths of German home electricity (including minor fuel-switching) with a $40 \% / y$ aftertax return on investment. Such findings with ever greater sophistication have been published worldwide since 1979, but are generally rejected by nontechnological economic theorists who argue that if such costeffective opportunities existed, they'd already have been captured in the marketplace, even in planned economies with no marketplace or mixed economies with a distorted one. This mental model- "Don't bother to bend over and pick up that banknote lying on the ground, because if it were real, someone would have picked it up already"-often dominates government policy. It seems ever less defensible as more is learned about the reality of pervasive market failures (Part 5) and the astonishing size and cheapness of the energy savings empirically achieved by diverse enterprises (Part 3). But by now, the debate has become theological (Part 3) -about whether existing markets are essentially perfect, as most economic modelers assume for comfort and convenience, or whether market failures are at least as important as market function and lie at the heart of business and policy opportunity. This seems a testable empirical question.

It may soon be tested in the transport sector. The author's team's uncontested analysis in the Pentagon-cosponsored independent study Winning the Oil Endgame, published in September 2004, found that $52 \%$ of the officially forecast U.S. 2025 oil use could be saved (half by then, half later as vehicle stocks turn over), at an average cost of just \$12/bbl (2000 \$). The remaining oil use could be displaced by saved natural gas and advanced biofuels at an average cost of $\$ 18 / \mathrm{bbl}$. Thus, by the 2040 s, the U.S. could use no oil and revitalize its economy, led by business for profit, and encouraged by public policies not requiring mandates, fuel taxes, subsidies, or 
new national laws. Rather, the transition would be driven by competitive strategy in the car, truck, plane, and oil industries, plus military needs. These findings surprised many, yet a year later, remain unchallenged. Early sectoral progress with implementation has been encouraging.

\section{E. Discontinuous technological progress}

This engineering/economics divergence about the potential to save energy also reflects a tacit assumption that technological evolution is smooth and incremental, as mathematical modelers prefer. In fact, while much progress is as incremental as technology diffusion, discontinuous technological leaps, more like "punctuated equilibrium" in evolutionary biology, can propel in-

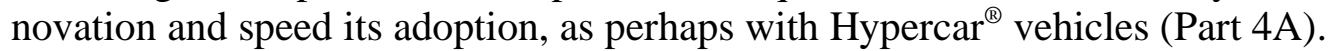

Technological discontinuities can even burst the traditional boundaries of possibility by redefining the design space:

- Generations of engineers learned that big supercritical-steam power plants were as efficient as possible-40-odd percent from fuel in to electricity out. But through sloppy learning or teaching, they'd overlooked the possibility of stacking two Carnot cycles atop each other. Such combined-cycle (gas-then-steam) turbines, based on mass-produced jet engines, can exceed 60\% efficiency and are cheaper and faster to build, so in the 1990s, they quickly displaced the big steam plants. Fuel cells, the next innovation, avoid Carnot limits altogether by being an electrochemical device, not a heat engine. Combining both may soon achieve 80-90\% fuel-to-electric efficiency. Even inefficient distributed generators can already exceed $90 \%$ system efficiency by artfully using recaptured heat.

- Pumps, fans, and other turbomachinery (the main uses of electricity) seemed a mature art until a novel biomimetic rotor (www.paxscientific.com), using laminar vortex flow instead of turbulent flow, proved substantially more efficient.

- The canonical theoretical efficiency limit for converting sunlight into electricity using single-layer photovoltaic (PV) cells is normally stated as $33 \%-50+\%$ using multicolor stacked layers, vs. lab values around $24 \%$ and $39 \%$ (lower in volume production). That's because semiconductor bandgaps were believed too big to capture any but the highenergy wavelengths of sunlight. But those standard data are wrong. A Russian-based team suspected in 2001, and Lawrence Berkeley National Laboratory proved in 2002, that indium nitride's bandgap is only $0.7 \mathrm{eV}$, matching near-infrared $(1.77 \mu \mathrm{m})$ light and hence able to harvest almost the whole solar spectrum. This may raise the theoretical limit to $50 \%$ for two-layer and to $\sim 70 \%$ for many-layer thin-film PVs. Perhaps opticaldimension lithographed antenna arrays or quantum-dot PVs can do even better.

Caution is likewise vital when interpreting Second Law efficiency (the ratio of the least available work that could have done the job to the actual available work used to do the job). In the macroscopic world, the laws of thermodynamics are normally considered ineluctable-but the definition of the desired change of state can be finessed. Ernie Robertson notes that when turning limestone into a structural material, one is not confined to the conventional possibilities of cutting it into blocks or calcining it at $\sim 1,250^{\circ} \mathrm{C}$ into Portland cement. One can instead grind it up and feed it to chickens, whose ambient-temperature technology turns it into eggshell stronger than Portland cement. Were we as smart as chickens, we would have mastered this life-friendly technology. Extraordinary new opportunities to harness 3.8 billion years of biological design experience, as described by Janine Benyus in Biomimicry, can often make heat-beat-and-treat in- 
dustrial processes unnecessary. So, in principle, can the emerging techniques of nanotechnology using molecular-scale self-assembly, as pioneered by Eric Drexler.

More conventional innovations can also bypass energy-intensive industrial processes. Making artifacts that last longer, use materials more frugally, and are designed and deployed to be repaired, reused, remanufactured, and recycled can save much or most of the energy traditionally needed to produce and assemble their materials (and can increase welfare while reducing GDP, which perversely swells when ephemeral goods are quickly discarded and replaced). Microfluidics can even shrink a big chemical plant to the size of a watermelon: millimeter-scale flow in channels etched into silicon wafers can control time, temperature, pressure, stoichiometry, and catalysis so exactly that a narrow product spectrum is produced, without the side-reactions that normally need most of the chemical plant to separate undesired from desired products.

Such "end-run" solutions-rather like the previous example of substituting sensible landuse for better vehicles, or better still, combining both — can greatly expand the range of possibilities beyond simply improving the narrowly defined efficiency of industrial equipment, processes, and controls. By combining many such options, it is now realistic to contemplate a long-run advanced industrial society that provides unprecedented levels of material prosperity with far less energy, cost, and impact than today's best practice. Part 4A, drawn from Paul Hawken et al.'s synthesis in Natural Capitalism and Ernst von Weizsäcker et al.'s earlier Factor Four, further illustrates recent breakthroughs in integrative design that can make very large energy savings cost less than small ones; and Part 6 summarizes similarly important discontinuities in policy innovation.

In light of all these possibilities, why does energy efficiency, in most countries and at most times, command so little attention and such lackadaisical pursuit? Several explanations come to mind. Saved energy is invisible. Energy-saving technologies may look and outwardly act just like inefficient ones, so they're invisible too. They're also highly dispersed-unlike central supply technologies that are among the most impressive human creations, inspiring pride and attracting ribbon-cutters and rent- and bribe-seekers. Many users believe energy efficiency is binary-you either have it or lack it — and that they already did it in the 1970s, so they can't do it again. Energy efficiency has relatively weak and scattered constituencies. And major energy efficiency opportunities are disdained or disbelieved by policymakers indoctrinated in a theoretical economic paradigm that claims big untapped opportunities simply cannot exist (Part 3).

\section{Benefits}

Energy efficiency avoids the direct economic costs and the direct environmental, security, and other costs of the energy supply and delivery that it displaces. Yet most literature neglects several key side-benefits (economists call them "joint products") of saving energy.

\section{A. Indirect benefits from qualitatively superior services}

Improved energy efficiency, especially end-use efficiency, often delivers better services. Efficient houses are more comfortable; efficient lighting systems can look better and help you see better; efficient motors can be more quiet, reliable, and controllable; efficient refrigerators can keep food fresher for longer; efficient cleanrooms can improve the yield, flexibility, throughput, and setup time of microchip fabrication plants; aerodynamically efficient chemical fume hoods can improve safety; airtight houses with constant controlled ventilation (typically 
through heat exchangers to recover warmth or coolth) have more healthful air than leaky houses that are ventilated only when wind or some other forcing function fortuitously blows air through cracks; efficient supermarkets can improve food safety and merchandising; retail sales pressure can rise $40 \%$ in well-daylit stores; students' test scores imply $\sim 20-26 \%$ faster learning in welldaylit schools. Such side-benefits can be one or even two more orders of magnitude more valu-

able than the energy directly saved. For example, careful measurements show that in efficient buildings - where workers can see what they're doing, hear themselves think, breathe cleaner air, and feel more comfortable-labor productivity typically rises by about 6-16\%. Since office workers in industrialized countries cost $\sim 100 \times$ more than office energy, a $1 \%$ increase in labor productivity has the same bottom-line effect as eliminating the energy bill—and the actual gain in labor productivity is $\sim 6-16 \times$ bigger than that. Practitioners can market these attributes without ever mentioning lower energy bills.

\section{B. Leverage in global fuel markets}

Much has been written about the increasing pricing power of major oil-exporting countries, especially Saudi Arabia with its important swing production capacity. Yet the market power of the United States - the Saudi Arabia of energy waste-is even greater on the demand side. The U.S. can save oil faster than OPEC can conveniently sell less oil. This was illustrated during 1977-85, when U.S. GDP rose $27 \%$ while total U.S. oil use fell 17\%, oil imports fell $50 \%$, and imports from the Persian Gulf fell 87\%. OPEC's exports fell $48 \%$ (one-fourth of this fall was due to U.S. action), breaking its pricing power for a decade. The most important single cause of the U.S. 5.2\%/y gain in oil productivity was more-efficient cars, each driving $1 \%$ fewer $\mathrm{km}$ on $20 \%$ less gasoline - a 7-mi/USgal gain in six years for new American-made cars-and $96 \%$ of those savings came from smarter design, only $4 \%$ from smaller size.

\section{Buying time}

Energy efficiency buys time. Time is the more precious asset in energy policy, because it permits the fuller and more graceful development and deployment of still better techniques for energy efficiency and supply. This pushes supply curves down towards the lower right (larger quantities at lower prices), postpones economic depletion, and buys even more time. The more time is available, the more information will emerge to support wiser and more robust choices, and the more fruitfully new technologies and policy options can meld and breed new ones. Conversely, hasty choices driven by supply exigencies almost always turn out badly, waste resources, and foreclose important options. Of course, once bought, time should be used wisely. Instead, the decade of respite bought by the U.S. efficiency spurt of 1977-85 was almost entirely wasted as attention waned, efficiency and alternative-supply efforts stalled, R\&D teams were disbanded, and political problems festered. We all pay today the heavy price of that stagnation.

\section{Integrating efficiency with supply}

To first order, energy efficiency makes supply cheaper. But second-order effects reinforce this first-order benefit, most obviously when efficiency is combined with onsite renewable supplies, making them nonlinearly smaller, simpler, and cheaper. For example:

- A hot-water-saving house can achieve a very high solar-water-heat fraction (e.g., 99\% in 
the author's home high in the Rocky Mountains) with only a small collector, so it needs little or no backup, partly because collector efficiency increases as stratified-tank storage temperature decreases.

- An electricity-saving house (the author's saves $~ 90 \%$, using only $\sim 110-120$ average W for $372 \mathrm{~m}^{2}$ ) needs only a few $\mathrm{m}^{2}$ of PVs and a simple balance-of-system (storage, inverter, etc.). This can cost less than connecting to the grid a few meters away.

- A passive-solar, daylit building needs little electricity, and can pay for even costly forms of onsite generation (such as PVs) by eliminating or downsizing mechanical systems.

- Such mutually reinforcing options can be bundled: e.g., 1.18 peak MW of photovoltaics retrofitted onto the Santa Rita Jail in Alameda County, California, was combined with efficiency and load management, so at peak periods when the power was most valuable, less was used by the jail and more sold back to the grid. This bundling yielded an internal rate of return over $10 \%$ including state subsidies, and a present-valued customer benefit/cost ratio of 1.7 without or 3.8 with those subsidies.

\section{E. Gaps in engineering economics}

Both engineers and economists conventionally calculate the cost of supplying or saving energy using a rough-and-ready toolkit called "engineering economics." Its methods are easy-touse but flawed, ignoring such basic tenets of financial economics as risk-adjusted discount rates. Indeed, engineering economics omits 207 economic and engineering considerations that together increase the value of decentralized electrical resources by typically an order of magnitude. Many of these "distributed benefits," compiled in the author's team's Small Is Profitable, apply as much to end-use efficiency as to decentralized generation. Most of the literature on the cost of energy alternatives is based solely on accounting costs and engineering economics that greatly understate efficiency's value. Properly counting its benefits will yield far sounder investments.

End-use efficiency is also the most effective way to make energy supply systems more resilient against mishap or malice, because it increases the duration of buffer stocks, buying time to mend damage or arrange new supplies, and it increases the share of service that curtailed or improvised supplies can deliver. Efficiency's high "bounce per buck" makes it the cornerstone of any energy system design for secure service provision in a dangerous world.

\section{Engineering $v s$. economic perspectives}

Engineering practitioners and economic theorists view energy efficiency through profoundly different lenses, yet both disciplines are hard pressed to explain such phenomena as:

- During 1996-2001, U.S. aggregate energy intensity fell at a near-record pace despite record-low and falling energy prices. (It fell faster only once in modern history, during the record-high and rising energy prices of 1979-85.) Apparently something other than price was getting Americans' attention.

- During 1990-96, when a kW-h of electricity cost only half as much in Seattle as in Chicago, people in Seattle, on average, reduced their peak electric load $12 \times$ as fast, and their use of electricity $\sim 3,640 \times$ as fast, as did people in Chicago-probably because the utility encouraged efficiency in Seattle but discouraged it in Chicago.

- In the 1990s, DuPont found that its European chemical plants were no more energyefficient than its corresponding U.S. plants, despite long having paid twice the energy 
price-probably because all plants were designed by the same people in the same ways with the same equipment, and there's little room for behavior change in a chemical plant.

- In Dow Chemical Company's Louisiana Division during 1981-93, nearly 1,000 projects to save energy and reduce waste added $\$ 110$ million/y to the bottom line and yielded returns on investment averaging over $200 \% / y$-yet in the latter years, both the returns and the savings were trending upwards as the engineers discovered new tricks faster than they used up the old ones. (Economic theory would deny the possibility of so much "lowhanging fruit" that has fallen down and is mushing up around the ankles: such enormous returns, if real, would long ago have been captured. This belief was the main obstacle to engineers' seeking such savings, then after their discovery, persisting to save even more.)

- Only about 25-35\% of apartment-dwellers, when told that their air-conditioner and electricity are free, behave as economists would predict - turning on the air conditioner when they feel hot and setting the thermostat at a temperature at which they feel comfortable. The rest show no correlation between air-conditioning usage and comfort; instead, their cooling behavior is determined by at least six other variables: household schedules, folk theories about air conditioners (such as that the thermostat is a valve that makes the cold come out faster), general strategies for dealing with machines, complex belief systems about health and physiology, noise aversion, and wanting white noise to mask outside sounds that might wake the baby. Energy anthropology reveals that both the economic and the engineering models of air-conditioning behavior are not just incomplete but seriously misleading. People are complex — not mere cost-benefit calculating machines.

- By 1990, the United States had misallocated \$1 trillion of investments to 200 million refrigerative tons of air conditioners, and $\sim 200$ peak GW (2/5 of total peak load) of power supply to run them, that would not have been bought if the buildings had been optimally designed to produce best comfort at least cost. This seems explicable by the perfectly perverse incentives seen by each of the twenty-odd actors in the commercial-real-estate value chain, each systematically rewarded for inefficiency and penalized for efficiency. Each of these market failures is both a potential show-stopper and a business opportunity.

- Not just individuals but also most firms, even large and sophisticated ones, routinely fail to make essentially riskless efficiency investments yielding many times their normal business returns: most require energy efficiency investments to yield $\sim 6 \times$ their marginal cost of capital, which typically applies to far riskier investments. This too is a huge business opportunity that smart firms are starting to exploit.

Many economists would posit some unknown error or omission in these descriptions, not in their theories. Indeed, energy engineers and energy economists seem not to agree about what is an hypothesis and what is a fact. Engineers take their facts from tools of physical observation. Three decades' conversations with noted energy economists suggest to the author that most think facts come only from observed flows of dollars, interpreted through indisputable theoretical constructs, and hence consider any contrary physical observations aberrant.

This divergence makes most energy economists suppose that buying energy efficiency faster than the "spontaneous" rate of observed intensity reduction (for 1997-2001, 2.7\%/y in the U.S., $1.4 \% / y$ E.U., $1.3 \% / y$ world, and $5.3 \% / y$ China) would require considerably higher energy prices, because if greater savings were profitable at prevailing prices, they'd already have been bought; thus engineers' bottom-up analyses of potential energy savings must be unrealistically high. Economists' estimates of potential savings at current prices are "top-down" and very small, based on historic price elasticities that confine potential interventions to changing prices and sav- 
ings to modest size and diminishing returns (otherwise the economists' simulation models would inconveniently explode). Engineers retort that high energy prices aren't necessary for very large energy savings (because they're so lucrative even at historically low prices, as at Dow Louisiana) but aren't sufficient either (because higher prices do little without enlarged ability to respond to them, as in the Seattle vs. Chicago example).

Of course, engineering-based practitioners agree that human behavior is influenced by price, as well as by convenience, familiarity, fashion, transparency, competing claims on attention, and many other marketing and social-science factors-missing from any purely technological perspective but central to day-to-day fieldwork. The main difference is that practitioners think these obstacles are "market failures" and dominate behavior in buying energy efficiency. Most economists deny this, and say efficiency's relatively slow adoption must be due to gross errors in the engineers' claims of how large, cheap, and available its potential really is.

This theological deadlock underlies the debate about climate protection. Robert Repetto and Duncan Austin showed in 1997 that all mainstream climate-economics models' outputs are hard-wired to their input assumptions, and that realistic inputs, conforming to the actual content of the Kyoto Protocol and its rules, show that climate protection increases GDP. Florentin Krause has shown that the main official U.S. Government analyses, taken together, concur. Yet the official White House position in 2005 is still that climate protection, even if desirable, cannot be mandated because it is too costly. By the time this view changes, private-sector and state- and local-government initiatives will have surpassed U.S. Kyoto obligations, and may have already.

In fact, climate protection is not costly but profitable; its critics may have the amount about right, but they got the sign wrong. Before debating whether the cost of climate protection is a big or a small number, one must understand that it's a negative number. The clearest proof is in the behavior and achievements of the smart companies that are behaving as if the U.S. had ratified the Kyoto Protocol, because energy efficiency costs less than the energy it saves. For example, such large firms as DuPont, IBM, and STMicroelectronics (the world's \#7 chipmaker) have lately been raising their energy productivity by $6 \% / y$ with simple paybacks of a few years. DuPont expected by 2010 to cut its greenhouse gas emissions by $65 \%$ below the 1990 level; STM, to zero (despite making 40x more chips). DuPont has in fact saved $72 \%$ so far; by 2004 it had raised output $30 \%$, cut energy use $7 \%$, and saved over $\$ 2$ billion net. Similarly, BP announced that its intended $10 \%$ carbon reduction by 2010 had been achieved eight years early at zero net cost; actually, the 10-year net-present-valued saving was $\$ 650$ million.

Such examples abound (www.cool-companies.org, www.pewclimate.org). These famous companies, and more all the time, are hardly naïve or deluded. (In 2005, GE pledged to boost its energy efficiency $30 \%$ by 2012 to increase shareholder value.) Anyone ignoring this market reality is mistaking the econometric rear-view mirror for a windshield. Econometrics measures how human populations behaved under past conditions that no longer exist and that it is often a goal of energy policy to change. Where price is the only important explanatory variable, econometrics can be a useful tool for extrapolating history into how price may influence near-term, small, incremental changes in behavior. But limiting our horizons to this cramped view of technical possibilities and human complexity rules out innovations in policies, institutions, preferences, and technologies - treating the future like fate, not choice, and thus making it so.

\section{Diminishing vs. expanding returns to investments in energy efficiency}


Among the most basic, most often skipped over, yet most simply resolved economic/engineering disagreements is whether investing in end-use efficiency yields expanding or diminishing returns. Economic theory says diminishing - the more efficiency we buy, the more steeply the marginal cost of the next increment of savings rises, until it becomes too expensive (Figure 2). But engineering practice often says expanding-big savings can cost less than small or no savings (Figure 3) - if the engineering is done unconventionally but properly.

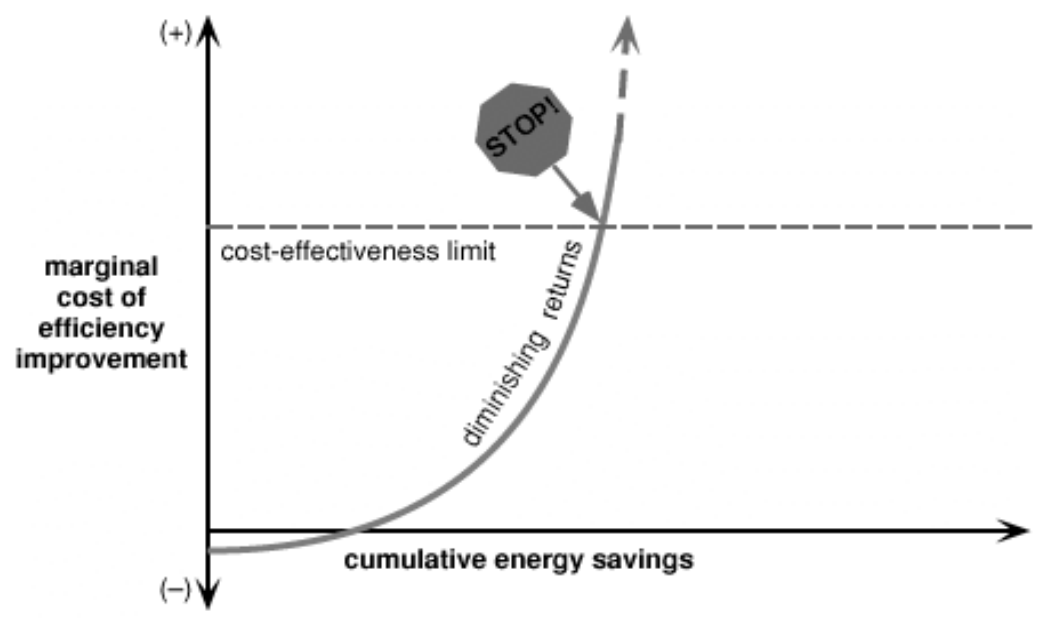

Fig. 2. Diminishing returns-greater energy savings incur greater marginal cost-can be true for some (not all) components, but need not be true for most systems.

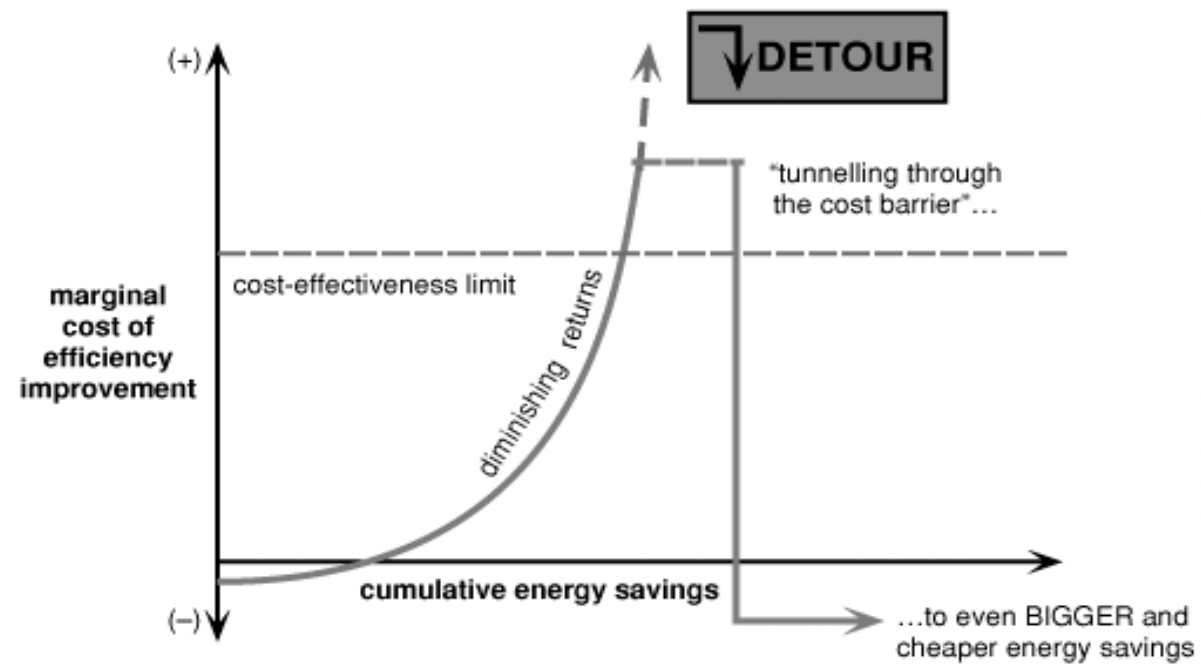

Fig. 3. Optimizing whole systems for multiple benefits, rather than isolated components for single benefits, can often "tunnel through the cost barrier" directly to the lower-right destination, making very large energy savings cost less than small or no savings. This has been empirically demonstrated in a wide range of technical systems.

\section{A. Empirical examples}


Consider, for example, how much thermal insulation should surround a house in a cold climate. Conventional design specifies just the amount of insulation that will repay its marginal cost out of the present value of the saved marginal energy. But this is methodologically wrong, because the comparison omits the capital cost of the heating system-furnace, ducts, fans, pipes, pumps, wires, controls, and fuel source. The author's house illustrates that in outdoor temperatures down to $-44^{\circ} \mathrm{C}$, it is feasible to grow bananas ( 28 crops so far) at $2200 \mathrm{~m}$ elevation in the Rocky Mountains with no heating system, yet with reduced construction cost, because the superwindows, superinsulation, air-to-air heat exchangers, and other investments needed to eliminate the heating system cost less to install than the heating system would have cost to install. The resulting $\sim 99 \%$ reduction in heating energy cost is an extra benefit, and it's better than free.

Similarly, Pacific Gas and Electric Company's Advanced Customer Technology Test for Maximum Energy Efficiency ("ACT"') demonstrated in seven new and old buildings in the 1990s that the "supply curve" of energy efficiency generally bent downwards, as shown schematically in Figure 3. For example, an ordinary-looking new tract house was designed to save $82 \%$ of the energy allowed by the strictest U.S. standard of the time (1992 California Title 24), yet PG\&E estimated that if widely practiced, not a single experiment, it would cost $\sim \$ 1,800$ less than normal to build and $\sim \$ 1,600$ less in present value to maintain. It provided comfort with no cooling system in a climate that can reach $45^{\circ} \mathrm{C}$; a similar house later did the same in a $46^{\circ} \mathrm{C}$ peak climate. And the $350-\mathrm{m}^{2}$ Bangkok house of architect Prof. Suntoorn Boonyatikarn provided normal comfort, with $16 \%$ of normal air-conditioning capacity, at no extra construction cost.

These examples illustrate how optimizing a house as a system rather than optimizing a component in isolation, and optimizing for lifecycle cost (capital plus operating cost, and preferably maintenance cost too), can make a superefficient house cheaper to build, not just to run, by eliminating costly heating and cooling systems. Similarly, a retrofit design for a $19,000-\mathrm{m}^{2}$ curtainwall office building near Chicago found $75 \%$ energy-saving potential at no more cost than the normal 20-year renovation that saves nothing, because the $\$ 200,000$ capital saving from making the cooling system $4 \times$ smaller (yet $4 \times$ more efficient), rather than renovating the big old system, would pay for the other improvements.

In a striking industrial example, a heat-transfer pumping loop originally designed to use $70.8 \mathrm{~kW}$ of pumping power was redesigned by Dutch engineer Jan Schilham (at Interface Nederland bv in Scherpenzeel) to use $5.3 \mathrm{~kW}-92 \%$ less-with lower capital cost and better performance, using no new technologies but only two changes in the design mentality:

- Use big pipes and small pumps rather than small pipes and big pumps. The friction in a pipe falls as nearly the fifth power (roughly -4.84) of its diameter. Engineers normally make the pipe just fat enough to repay its greater cost from the saved pumping energy. This calculation improperly omits the capital cost of the pumping equipment-the pump, motor, inverter, and electricals that must overcome the pipe friction. Yet the size and roughly the cost of that equipment will fall as nearly the fifth power of pipe diameter, while the cost of the fatter pipe will rise as only about the second power of diameter. Thus conventionally optimizing the pipe as an isolated component actually pessimizes the system! Optimizing the whole system together will clearly yield fat pipes and tiny pumps, so total capital cost falls slightly and operating cost falls dramatically.

- Lay out the pipes first, then the equipment. Normal practice is the opposite, so the connected equipment is typically far apart, obstructed by other objects, at the wrong height, and facing the wrong way. The resulting pipes have $\sim 3-6 \times$ as much friction as they'd 
have with a straight shot - to the delight of the pipefitters, who are paid by the hour, mark up a profit on the extra pipes and fittings, and don't pay for the extra electricity or bigger pumping equipment. But the owner would do better with fat, short, straight pipes than thin, long, crooked pipes.

Together, these two design changes cut the measured pumping power by $12 \times$, with lower capital cost and better performance. They also saved $70 \mathrm{~kW}$ of heat loss with a 2-month payback, because it's easier to insulate short, straight pipes. In hindsight, however, the design was still suboptimal, because it omitted seven additional benefits: less space, weight, and noise; better maintenance access; lower maintenance cost; higher reliability and uptime; and longer life (because the removed pipe elbows won't be eroded by fluid turning the corner). Properly counting these seven benefits too would have saved not $92 \%$ but nearer $98 \%$ of the energy and cost even less, so about a factor-four potential saving was left uncaptured.

Other recent design examples include a $97 \%$ reduction in air-conditioning energy for a California office retrofit, with attractive returns and better comfort; lighting retrofit savings upwards of $90 \%$ with better visibility and a 1-2-y payback; an energy cost reduction $>40 \%$ with a 3 -y payback in retrofitting an already very efficient oil refinery; $\sim 75 \%$ electrical savings in a new chemical plant, with $\sim 10 \%$ lower construction time and cost; $\sim 89 \%$ in a new data center at lower cost; $70-90 \%$ in a new supermarket at probably lower cost; and $20 \%$ of energy and $33 \%$ of water in a new chip fab with $30 \%$ lower construction cost (the next fab, using two big options not tested quite in time for the first one, will save far more energy, yet cost even less to build).

The obvious lesson is that optimizing whole systems for multiple benefits, not just components for single benefits, often boosts end-use efficiency by roughly an order of magnitude at negative marginal cost. These enormous savings were not previously much noticed or captured because of deficient engineering pedagogy and practice. (The author hopes to collect such examples into a $10 x E$-Factor Ten Engineering — casebook to drive pedagogic reform.) Whole-system design integration isn't rocket science, but rediscovers the forgotten tradition of Victorian system engineering, before designers got specialized and forgot how components fit together.

It's not even generally true, as economic theory supposes, that greater end-use efficiency costs more at the level of components. For example, the most common type of industrial motor on the 1996 U.S. market (1800-rpm TEFC, NEMA Design B) exhibited no empirical correlation whatever between efficiency and price up to at least $225 \mathrm{~kW}$. (Premium-efficiency motors should cost more to build because they contain more and better copper and iron, but they're not priced that way.) The same is true for most industrial pumps and rooftop chillers, Swedish refrigerators, American televisions, and many other products. But even if it were not true, artfully combining components into systems can definitely yield expanding returns.

Perhaps the most consequential example is in light vehicles. A small private company completed in 2000 the manufacturable, production-costed virtual design (Lovins \& Cramer 2004) of a midsize-sport-utility-vehicle concept car that is uncompromised, cost-competitive, zero-emission, and quintupled-efficiency. It is so efficient $(2.1 \mathrm{~L} / 100 \mathrm{~km})$ not just because its direct-hydrogen fuel cell is about twice as efficient as a gasoline-fueled Otto engine, but also because it is so lightweight (but crashworthy) and so low in aerodynamic drag and rolling resistance that it can cruise at highway speed on no more power to the wheels than a conventional SUV uses on a hot day just for air conditioning. This design suggests that cars, too, can "tunnel through the cost barrier," achieving astonishing fuel economy at no extra cost and with many other customer and manufacturing advantages. With aggressive licensing of existing intellectual property, such vehicles could start ramping up production as early as 2010. All major automakers 
have had parallel development programs underway, totaling $\sim \$ 10$ billion of related commitments through 2000, since the basic concept was put into the public domain in 1993 to maximize competition. Further analysis in Winning the Oil Endgame showed that ultralighting with carbonthermoplastic composites (backstopped by ultralight steels) would nearly double the efficiency of today's gasoline-hybrid cars, yielding $3.6 \mathrm{~L} / 100 \mathrm{~km}$ for such a midsize SUV or $\sim 2.6$ for a typical car (all with projected U.S. 2025 size, acceleration, and safety). Yet their production cost would be the same as for hybrid cars today, because the composites' extra cost is offset by simpler automaking and smaller powertrain. The $3.6 \mathrm{~L} / 100 \mathrm{~km}$ SUV would thus pay back in a year at today's E.U. or in two years at today's U.S. gasoline prices. Its safety would improve, because its halved curb weight is more than offset by carbon thermoplastic structures' $\sim 12 \times$ greater crash energy absorption per $\mathrm{kg}$ than steel. The needed breakthrough in low-cost advanced-composite manufacturing is now being commercialized (www.fiberforge.com).

A full U.S. fleet of such light vehicles of various shapes and sizes would save about as much oil as Saudi Arabia produces ( 9-12 Mbbl/d); a global fleet, as much oil as OPEC sells. Moreover, if fuel-cell-powered, such vehicles can be designed to plug into the grid when parked (as the average car is $\sim 96 \%$ of the time) as a power station on wheels, selling back enough electricity and ancillary services to repay most of its cost. A U.S. fleet of light vehicles doing this would have $\sim 6-12 \times$ as much electric generating capacity as all power companies now own. This is part of a wider strategy that combines hydrogen-ready vehicles with integrated deployment of fuel cells in stationary and mobile applications to make the transition to a climate-safe hydrogen economy profitable at each step starting now (beginning with ultrareliable combined-heat-andpower in buildings). The resulting displacement of power plants, oil-fueled vehicles, and fossilfueled boilers and furnaces could decrease net consumption of natural gas, could save about \$1 trillion of global vehicle refueling investment over the next 40 years (compared with gasolinesystem investment), and could profitably displace up to two-thirds of $\mathrm{CO}_{2}$ emissions. It could also raise the value of hydrocarbon reserves, whose hydrogen is typically worth more without than with the carbon. It is favored by many leading energy and car companies today. And it is not too far off: more than two-thirds of the fossil-fuel atoms burned in the world today are already hydrogen, and global hydrogen production ( $50 \mathrm{MT} / \mathrm{y})$, if diverted from its present uses, could fuel an entire fleet of superefficient U.S. highway vehicles. (So could windpower on available land just in the Dakotas, or reforming much of the half of U.S. natural gas that Winning the Oil Endgame found could be saved for $<\$ 1 / \mathrm{GJ}$.) The business case for hydrogen is robust if and only if vehicles are superefficient. But if they are, then the hydrogen tanks for a normal driving range (530 km for the concept SUV above) become 3x smaller-small enough to package well with no new storage technology — and the fuel cells, also $3 \times$ smaller, become affordable far earlier: at an $80 \%$ experience curve, $\sim 32 \times$ less cumulative production is needed for competitive cost.

\section{B. The right steps in the right order}

Such breakthrough results need not just the right technologies but also their application in the right sequence. For example, most practitioners designing lighting retrofits start with more efficient luminaires-improving optics, lamps, and ballasts. But for optimal energy and capital savings, that should be step six, not step one. First come improving the quality of the visual task, optimizing the geometry and cavity reflectance of the space, optimizing lighting quality and quantity, and harvesting daylight. Then, after the luminaire improvements, come better controls, maintenance, management, and training. 
Likewise, to deliver thermal comfort in a hot climate, most engineers retrofit a more efficient and perhaps variable-speed chiller, variable-speed supply fans, etc. But these should all be step five. The previous four steps are to expand the comfort range (by exploiting such variables as radiant temperature, turbulent air movement, and ventilative chairs); reduce unwanted heat gains within or into the space; exploit passive cooling (ventilative, radiative, ground-coupling); and if needed, harness nonrefrigerative alternative cooling (evaporative, desiccant, absorption, and their hybrids like Pennington cycles). These preliminary steps can generally eliminate refrigerative cooling. If it's nonetheless still wanted, it can be made superefficient (COP 6.9 for supply fan through cooling tower in Singapore), then supplemented by better controls and coolth storage. Yet most designers pursue these seven steps in reverse order, worst buys first, so they save less energy, pay higher capital costs, yet achieve worse comfort and greater complexity.

Whole-system engineering optimizes for many benefits: there are, for example, ten benefits of superwindows, and 18 of premium-efficiency motors or dimmable electronic lighting ballasts, not just the one normally counted. (The arch that holds up the middle of the author's house has 12 different functions but is paid for only once.) Superwindows cost more per window, but typically make the whole building cost less because they downsize or eliminate spaceconditioning equipment. (They combine spectrally selective coatings with krypton fill to insulate as well as $\sim 8-12+$ sheets of glass, and for hot climates, they can almost perfectly admit light without heat.) Similarly, 35 retrofits to a typical industrial motor system, properly counting multiple benefits, can typically save about half its energy (not counting the larger and cheaper savings that should first be captured further downstream, e.g. in pumps and pipes) with a 16-month simple payback against a $5 \varnothing / \mathrm{kW}$-h tariff (as of 1986; it costs less today). The saving is so cheap because buying first the correct seven improvements yields 28 more as free byproducts. Such motor-system savings alone, if fully implemented, could save $\sim 30 \%$ of the world's electricity.

Such design requires a diverse background, deep curiosity, often a transdisciplinary design team, and meticulous attention to detail. Whole-system design is not what any engineering school appears to be teaching, nor what most customers currently expect, request, reward, or receive. But it represents a key part of the "overhang" of practical, profitable, unbought energy efficiency that so far remains missing from virtually all official studies.

\section{Market failures and business opportunities}

In a typical U.S. office, using one-size-fatter wire to power overhead lights would pay for itself within 20 weeks. Why wasn't that done? Because: (1) The wire size was specified by the low-bid electrician, who was told to "meet code," and the wire-size table in the [U.S.] National Electrical Code is meant to prevent fires, not to save money. Saving money by optimizing resistive losses takes wire about twice as fat. (2) The office owner or occupant will buy the electricity, but the electrician bought the wire. An electrician altruistic enough to buy fatter wire isn't the low bidder and won't win the job. Correcting this market failure needs attention both to the split incentive and to the misinterpretation of a life-safety regulation as an economic optimum.

This micro-example illustrates the range and depth of market failures that any skilled practitioner of energy efficiency encounters daily. A 1997 compendium, "Climate: Making Sense and Making Money," organizes 60-80 such market failures into eight categories-and illustrates the business opportunity each can be turned into. Some arise in public policy, some at the level of the firm, some in individuals' heads. Most are glaringly perverse. For example, in all but two of the United States, and in almost every other country, regulated distribution utilities are 
rewarded for selling more energy and penalized for cutting customers' bills, so they're unenthusiastic about energy efficiency that hurts their shareholders. Nearly all architects and engineers, too, are paid for what they spend, not for what they save; "performance-based fees" have been shown to yield superior design, but are rarely used. Most firms set discounted-cashflow targets for their financial returns, yet tell their operating engineers to use a simple-payback screen for energy-saving investments (typically less than two years), and the disconnect between these two metrics causes and conceals huge misallocations of capital. And when markets and bidding systems are established to augment or replace traditional regulation of energy supply industries, negawatts (saved watts) are rarely allowed to compete against megawatts. Indeed, dominant industries discourage competing investments by spreading disinformation. For example, from widely accepted but false claims that only nuclear power is big and fast enough to do much about climate change, one would hardly guess that its low- and no-carbon decentralized competitors already exceed its global output and capacity, and are adding manyfold more MW and TWh/y every year - an order of magnitude more if electrical savings are included too (Lovins 2005a).

In short, scores of market failures - well understood but widely ignored-cause available and profitable energy efficiency to get only a small fraction of the investment it merits. Thus most of the capital invested in the energy system is being misallocated. (The U.S. Energy Policy Act of 2005, repeating the errors of the early 1980s, greatly increases the diversion of private capital from market winners to market losers via hugely distorting new subsidies to the losers.) The most effective remedy would be to put systematic "barrier-busting"-turning obstacles into opportunities, stumbling-blocks into stepping-stones - atop the policy agenda, so market mechanisms could work properly, as economic theory correctly prescribes.

Using energy in a way that saves money is not only a perquisite of the rich; it is also arguably the most powerful key to global economic development for the poor. Making quintupledefficiency compact fluorescent lamps in Bombay or superwindows in Bangkok takes about a thousand times less capital than expanding the supply of electricity to produce the same light and comfort via inefficient lamps and office/retail air-conditioners. The efficiency investment is also repaid about ten times faster. The resulting $\sim 10,000 \times$ decrease in capital requirements could turn the power sector-which now uses about one-fourth of global development capital-into a net exporter of capital to fund other development needs. (That's why it's vital to track and label, then tax, restrict, or at least stigmatize the global trade in very inefficient electricity-using devices-an invisible trade whose perverse capital leverage probably causes as much human misery as drugs.) Likewise at the micro-scale of a rural village, a package of photovoltaics and superefficient end-use devices (lamps, pumps, mobile phone, water purification, vaccine refrigerator, GPS mapper for land titling, etc.), with normal utility financing and no subsidy, often incurs debt service lower than the villagers were already paying for lighting kerosene, candles, and radio batteries, so they have a positive cashflow from day one.

Conversely, when Chinese authorities imported many assembly lines to make refrigerators more accessible, the saturation of refrigerators in Beijing households rose from $2 \%$ to $62 \%$ in six years, but the refrigerators' inefficient design created unintended shortages of power and of capital to generate it (an extra half-billion dollars' worth). A State Council member said this error must not be repeated: energy and resource efficiency must be the cornerstone of the development process. Otherwise resource waste will require supply-side investment of the capital meant to buy the devices that were supposed to use those resources. This realization contributed to China's emphasis on energy efficiency (halving primary energy/GDP elasticity in the 1980, then nearly re-halving it again), laying the groundwork for the dramatic 1996 shift from coal- 
centric policy toward gas, renewables, and efficiency. This important contribution to reducing global carbon emissions was a byproduct of two other domestic goals-de-bottlenecking China's development and improving public health. In June 2004, the State Council approved a visionary energy policy framework based on strong efficiency and leapfrog technologies. Least-cost implementation in this spirit would mean investing an order of magnitude more in efficiency than supply — not, as historically, the reverse - and would greatly accelerate Chinese development and set a strong example for OECD countries.

\section{Old and new ways to accelerate energy efficiency}

\section{A. Old but good methods}

In the 1980s and 1990s, practitioners and policymakers greatly expanded their toolkits for implementing energy efficiency. During 1973-86, the U.S. doubled its new-car efficiency, and during 1977-85, cut national oil intensity 5.2\%/y. In 1983-85, ten million people served by Southern California Edison Company were cutting its decade-ahead forecast of peak load by $8 \frac{1}{2} \% / y$, at $\sim 1 \%$ the long-run marginal cost of supply. In 1990, New England Electric System signed up $90 \%$ of a pilot market for small-business retrofits in two months. In the same year, Pacific Gas and Electric Company marketers captured a fourth of the new-commercial-construction market for design improvements in three months, so in 1991, PG\&E raised the target-and got it all in the first nine days of January.

Such impressive achievements resulted from nearly two decades' refinement of program structures and marketing methods. At first, utilities and governments wanting to help customers save energy offered general, then targeted, information, and sometimes loans or grants. Demonstration programs proved feasibility and streamlined delivery. Standards knocked the worst equipment off the market. (Congress did this for household appliances without a single dissenting vote, because so many appliances are bought by landlords, developers, or public housing authorities - a manifest split incentive with the householders who'll later pay the energy bills.) Just refrigerator standards cut new U.S. units' electricity usage by fourfold during 1975-2001$5 \% / y$ - saving $40 \mathrm{GW}$ of electric supply. In Canada, labeling initially did nearly as well. Utilities began to offer rebates - targeted, then generic - to customers, then to other value-chain participants-for adopting energy-saving equipment, or scrapping inefficient equipment, or both. Some rebate structures proved potent, such as paying a shop assistant a bonus for selling an energyefficient refrigerator but nothing for selling an inefficient one. So did leasing (20ф per compact fluorescent lamp per month, so you pay for it over time just like a power plant... but the lamp is far cheaper), paying for better design, and rewarding buyers for beating minimum standards. Energy-saving companies, independent or utility-owned, provided turnkey design and installation to reduce hassle. Sweden aggregated technology procurement to offer "golden carrot" rewards to manufacturers bringing innovations to market; once these new products were introduced, competition quickly eliminated their modest price premia.

These engineered-service-delivery models worked well, often spectacularly well. Steve Nadel's 1990 review of 237 programs at 38 U.S. utilities found many costing <1 $\not / \mathrm{kWh}(1988 \$)$. During 1991-94, the entire demand-side-management portfolio of California's three major investor-owned utilities saved electricity at an average program cost that fell from about 2.8 to 1.9 current $\phi / \mathrm{kW}$-h $(1.2 \phi$ for the cheapest), saving society over $\$ 2$ billion more than the effort cost. 


\section{B. New and better methods}

Since the late 1980s, another model has been emerging that promises even better results: not just marketing negawatts (saved watts)—maximizing how many customers save and how much — but also making markets in negawatts-thus maximizing competition in who saves and how, so as to drive quantity and quality up and cost down. Competitive bidding processes let saved and produced energy compete fairly. Savings can be made fungible in time and space, transferred between customers, utilities, and jurisdictions, and procured by "bounty-hunters." Spot, futures, and options markets can be expanded from just megawatts to embrace negawatts too, permitting arbitrage between them. Property owners can commit never to use more than $x$ MW, then trade those commitments in a secondary market that values reduced demand and reduced uncertainty of demand. Efficiency can be cross-marketed between electric and gas distributors, each rewarded for saving either form of energy. Revenue-neutral "feebates" for connecting new buildings to public energy supplies-fees for inefficiency, rebates for efficiencycan reward continuous improvement. Standardized measurement and reporting of energy savings lets them be aggregated and securitized like home mortgages, sold promptly into liquid secondary markets, and hence financed easily and cheaply (www.ipmvp.org). Efficiency techniques can be conveniently bundled and translated to "vernacular" forms-easily chosen, purchased, and installed. Novel real-estate value propositions emerge from integrating efficiency with onsite renewable supply (part of the revolutionary shift now underway to distributed resources) so as to eliminate all wires and pipes, the trenches carrying them, and the remote infrastructure they connect to. Performance-based design fees, targeted mass retrofits, greater purchasing aggregation, and systematic barrier-busting all show immense promise. And aggressively scrapping inefficient devices-paying bounties to destroy them instead of reselling them-could both solve many domestic problems (e.g., oil, air, and climate in the case of inefficient vehicles) and boost global development by reversing "negative technology transfer."

Winning the Oil Endgame offers a similarly novel policy menu for saving oil. Revenueand size-neutral "feebates" for widening the price spread between more and less efficient light vehicles in each size class - thus arbitraging the discount-rate spread between car-buyers and society-are far more effective than fuel taxes or efficiency standards, and can yield both consumer and producer surpluses. Tripled-efficiency heavy trucks and planes can be elicited, respectively, by “demand pull” from big customers (once they're informed of what's possible, as began to occur in 2005) and by innovative financing for insolvent airlines (on condition of scrapping inefficient parked planes). The first $25 \%$ fuel saving for trucks and $20 \%$ for planes (in Boeing's 787 Dreamliner) is free; the rest of the tripling of efficiency has very high returns.

A key player may be the military, which needs superefficient platforms for agile deployment and to cut the huge cost and risk of fuel logistics. Speeding ultralight, ultrastrong materials fabrication processes to market could transform civilian vehicle industries as profoundly as military R\&D did to create the Internet, GPS, jet engines, and chips. Only this time, that transformation could lead countries like the U.S. off oil, making oil no longer worth fighting over.

Altogether, the conventional agenda for promoting energy efficiency-prices and taxes, plus regulation or deregulation-ignores nearly all the most effective, attractive, transideological, and quickly spreadable methods. And it ignores many of the new marketing "hooks" just starting to be exploited: security (national, community, and individual), economic development and balance of trade, avoiding price volatility and costly supply overshoot, profitable integration and bundling with renewables, and expressing individual values. 
Consider, for example, a good compact fluorescent lamp. It emits the same light as an in-

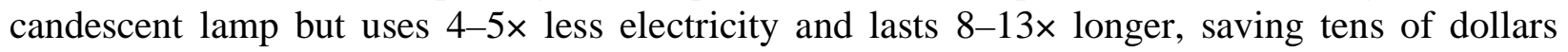
more than it costs. It avoids putting a ton of carbon dioxide and other pollutants into the air. But it does far more. In suitable volume - about a billion are now made each year-it can cut by a fifth the evening peak load that causes blackouts in overloaded Mumbai, can boost poor American chicken farmers' profits by a fourth, or can raise destitute Haitian households' disposable cash income by up to a third. As mentioned above, making the lamp requires $99.97 \%$ less capital than does expanding the supply of electricity, thus freeing investment for other tasks. The lamp cuts power needs to levels that make solar-generated power affordable, so girls in rural huts can learn to read at night, advancing the role of women. One light bulb does all that. You can buy it at the supermarket and install it yourself. One light bulb at a time, we can make the world safer. "In short," concludes Jørgen Nørgård, by pursuing the entire efficiency potential systematically and comprehensively, "it is possible in the course of half a century to offer everybody on Earth a joyful and materially decent life with a per capita energy consumption of only a small fraction of today's consumption in the industrialized countries...."

\section{De-emphasizing traditionally narrow price-centric perspectives}

These burgeoning opportunities suggest that price may well become less important to the uptake of energy efficiency. Price remains important and should be correct, but is only one of many ways to get attention and influence choice; ability to respond to price can be far more important. End-use efficiency may increasingly be marketed and bought mainly for its qualitatively improved services, just as distributed and renewable supply-side resources may be marketed and bought mainly for their distributed benefits. Outcomes would then become decreasingly predictable from economic experience or using economic tools.

Meanwhile, disruptive technologies and integrative design methods are clearly inducing dramatic shifts of, not just along, demand curves, and are even making them less relevant by driving customer choice through non-price variables. Ultralight-hybrid Hypercar ${ }^{\circledR}$ vehicles, for example, would do an end-run around two decades of trench warfare in the U.S. Congress (raising efficiency standards vs. gasoline taxes). They would also defy the standard assumption that efficient cars must trade off other desirable attributes (size, performance, price, safety), requiring government intervention to induce customers to buy the compromised vehicles. If, as now seems incontrovertible, light vehicles can achieve 3-5x fuel savings as a byproduct of breakthrough design integration, yet remain uncompromised and competitively priced, then the energy-pricedriven "tradeoff" paradigm becomes irrelevant. People will prefer such vehicles because they're better, not because they're clean and efficient, much as most people now buy digital media rather than vinyl phonograph records: they're a superior product that redefines market expectations. This implies a world where energy price and regulation become far less influential than today, displaced by imaginative, holistic, integrative engineering and marketing.

In the world of consumer electronics - ever better, faster, smaller, cheaper-that world is

upon us. In the wider world of energy efficiency, the master key to so many of the world's most vexing problems, it is coming rapidly over the horizon. We need only understand it and do it. And as inventor Edwin Land said, "People who seem to have had a new idea have often only stopped having an old idea." To think truly "outside the barrel," in the apt phrase of Rijkman Groenink (Chairman of ABN Amro's supervisory board), we all have much to unlearn. 


\section{BIBLIOGRAPHY}

American Institute of Physics (1975). Efficient Use of Energy, AIP Conf. Procs. \#25. AIP, New York. Benyus, J.M. (1997). Biomimicry: Innovation Inspired by Nature. William Morrow, New York. Brohard, G.J., Brown, M.W., Cavanagh, R., Elberling, L.E., Hernandez, G.R., Lovins, A., and Rosenfeld, A.H. (1998). "Advanced Customer Technology Test for Maximum Energy Efficiency (ACT ${ }^{2}$ ) Project: The Final Report." Procs. Summer Study on Energy-Efficient Buildings. American Council for an EnergyEfficient Economy, Washington, DC.

Daly, H.E. (1996) Beyond Growth-The Economics of Sustainable Development, Beacon Press, Boston. Drexler, K.E. (1992). Nanosystems: Molecular Machinery, Manufacturing, and Computation. John Wiley and Sons, New York.

E SOURCE (2002). Technology Atlas series (6 vols.) and Electronic Encyclopedia CD-ROM. E SOURCE, Boulder, Colorado, www.esource.com.

Fiberforge, Inc. (Glenwood Springs, Colorado), advanced-composites manufacturing process information at www.fiberforge.com.

Fickett, A.P., Gellings, C.W., and Lovins, A.B. (1990). "Efficient Use of Electricity." Sci. Amer. 263(3):64-74 (September).

Hawken, P.G., Lovins, A.B. and L.H. (1999). Natural Capitalism: Creating the Next Industrial Revolution. Little Brown, New York, www.natcap.org.

IPSEP (1989-99). Energy Policy in the Greenhouse. Report to Dutch Ministry of Environment, International Project for Sustainable Energy Paths, El Cerrito CA 94530, www.ipsep.org.

Johansson, T.B., Bodlund, B., and Williams, R.H., eds. 1989: Electricity. Lund University Press, Lund, Sweden, particularly Bodlund et al.'s chapter "The Challenge of Choices."

Koplow, D., "Energy Subsidy Links Pages," Earthtrack (Washington DC), 2005,

http://earthtrack.net/earthtrack/index.asp?page_id=177\&catid=66>http://earthtrack.net/earthtrack/index.as p?page_id $=177 \&$ catid $=66$

Krause, F., Baer, P., and DeCanio, S. (2001). "Cutting Carbon Emissions at a Profit: Opportunities for the U.S.” IPSEP, El Cerrito, California, www.ipsep.org/latestpubs.html.

Lovins, A.B. (1992). Energy-Efficient Buildings: Institutional Barriers and Opportunities. Strategic Issues Paper II. E SOURCE, Boulder, Colorado, www.esource.com.

Lovins, A.B. (1994). “Apples, Oranges, and Horned Toads.” Electricity J. 7(4):29-49.

Lovins, A.B. (1995). "The Super-Efficient Passive Building Frontier.” ASHRAE J. 37(6):79-81, June; RMI Publication \#E95-28, Rocky Mountain Institute, Snowmass, Colorado, www.rmi.org .

Lovins, A.B. (2003). "Twenty Hydrogen Myths,” www.rmi.org/sitepages/pid171.php\#20H2Myths.

Lovins, A.B. (2004). "Energy efficiency, taxonomic overview," Encyc. of Energy 2:382-401, Elsevier, free download at www.rmi.org/images/other/Energy/E04-02_EnergyEffTax.pdf.

Lovins, A.B. (2005). "More Profit With Less Carbon," Sci. Amer. 293:74-82, Sept., www.rmi.org/sitepages/pid171.php\#E05-05.

Lovins, A.B. (2005a). "Nuclear economics and climate-protection potential," Rocky Mountain Institute, 11 Sept. 2005, free download at www.rmi.org/sitepages/pid171.php\#E05-08.

Lovins, A.B. and Cramer, D.R. (2003). Hypercars ${ }^{\circledR}$, Hydrogen, and the Automotive Transition. Intl. J. Veh. Design, 35(1/2):50-85, www.rmi.org/images/other/Trans/T04-01_HypercarH2AutoTrans.pdf.

Lovins, A.B., Datta, E.K., Feiler, T., Rábago, K.R., Swisher, J.N., Lehmann, A., and Wicker, K. (2002).

Small Is Profitable: The Hidden Economic Benefits of Making Electrical Resources the Right Size. Rocky Mountain Institute, Snowmass, Colorado, www.smallisprofitable.org.

Lovins, A.B., and Gadgil, A. (1991). "The Negawatt Revolution: Electric Efficiency and Asian Development.” RMI Publication \#E91-23. Rocky Mountain Institute, Snowmass, Colorado.

Lovins, A.B., Datta, E.K., Bustnes, O.-E., Koomey, J.G., and Glasgow, N. (2004). Winning the Oil Endgame, Rocky Mountain Institute, Snowmass, Colorado, www.oilendgame.com. 
Lovins, A.B. \& L.H. (1991). "Least-Cost Climatic Stabilization.” Annual Review of Energy and the Environment 16:433-531.

Lovins, A.B. \& L.H. (1996). "Negawatts: Twelve Transitions, Eight Improvements, and One Distraction." Energy Policy 24(4):331-344, www.rmi.org/images/other/E-Negawatts12-8-1.pdf.

Lovins, A.B. \& L.H. (1997). "Climate: Making Sense and Making Money.” Rocky Mountain Institute, Snowmass, Colorado, www.rmi.org/images/other/C-ClimateMSMM.pdf.

Lovins, A.B. \& L.H. (2001). "Fool's Gold in Alaska." Foreign Affairs 80(4):72-85, July/August; annotated at www.rmi.org/images/other/E-FoolsGoldAnnotated.pdf.

Lovins, A.B. \& L.H., Krause, F., and Bach, W. (1982). Least-Cost Energy: Solving the $\mathrm{CO}_{2}$ Problem. Brick House, Andover, Massachusetts. Reprinted 1989 by Rocky Mountain Institute, Snowmass, Colorado.

Lovins, A.B., and Williams. B.D. (1999). “A Strategy for the Hydrogen Transition.” Procs. $10^{\text {th }}$ Ann. Hydrogen Mtg., 8 April, National Hydrogen Assn., Washington, DC, www.rmi.org/images/other/HCStrategyHCTrans.pdf.

Nadel. S. (1990). Lessons Learned. Report \#90-08. New York State Energy R\&D Authority (Albany), with N.Y. State Energy Office and Niagara Mohawk Power Corp. American Council for an EnergyEfficient Economy, Washington, DC.

Nørgård, Jørgen S. (2002). "Energy Efficiency and the Switch to Renewable Energy Sources. Natural Resource System Challenge II: Climate Change. Human Systems and Policy" (ed. A. Yotova), UNESCO Encyclopedia of Life Support Systems, EOLSS Publisher Co., Oxford, UK.

Reddy, A.K.N., Williams, R.H., and Johansson, T.B. (1997). Energy After Rio: Prospects and Challenges. United Nations Development Program, New York.

Repetto, R., \& Austin, D. (1997). "The Costs of Climate Protection: A Guide to the Perplexed.” World Resources Institute, Washington, DC, www.wri.org/wri/climate/.

Romm, J.J., Rosenfeld, A.H., and Herrmann, S. (1999). "The Internet Economy and Global Warming: A Scenario of the Impact of E-Commerce on Energy and the Environment." Center for Energy and Climate Solutions, Washington, DC, www.cool-companies.org.

Romm, J.J., and Browning, W.D. (1994). "Greening the Building and the Bottom Line: Increasing Productivity Through Energy-Efficient Design.” Rocky Mountain Institute, Snowmass, Colorado, www.rmi.org/sitepages/pid174.php.

Swisher, J.N. (2002). "The New Business Climate.” Rocky Mountain Institute, Snowmass, Colorado, www.rmi.org/store/p385pid2421.php.

Swisher, J.N., Jannuzzi, G., and Redlinger, R. (1998). Tools and Methods for Integrated Resource Planning: Improving Energy Efficiency and Protecting the Environment, UNEP Collaborating Centre on Energy and Environment, Denmark, http://www.uccee.org/IRPManual/index.htm.

von Weizsäcker, E.U., Lovins, A.B. \& L.H. (1995/97). Factor Four: Doubling Wealth, Halving Resource Use. Earthscan, London.

Wilson, A., Uncapher, J., McManigal, L., Lovins, L.H., Cureton, M., and Browning, W. (1998). Green Development: Integrating Ecology and Real Estate. John Wiley \& Sons, New York; Green Developments CD-ROM (2002), Rocky Mountain Institute, Snowmass, Colorado.

\section{ACKNOWLEDGMENTS}

The author is grateful to many colleagues, especially Drs. David B. Brooks, Jørgen S. Nørgård, and Joel N. Swisher PE for their insightful comments, and to The William and Flora Hewlett Foundation for supporting the preparation of an Encyclopedia of Energy article (Lovins 2004) from which this paper was adapted and updated with IAC's consent. 